The Best Paper of the Year

Longitudinal Measurements and Developmental Patterns of Receptive Vocabulary Size:

A Study of Japanese University EFL Students

Kazuhiko KATAGIRI (Senshu University) 


\title{
Longitudinal Measurements and Developmental Patterns of Receptive Vocabulary Size: A Study of Japanese University EFL Students
}

\author{
Kazuhiko KATAGIRI \\ Senshu University
}

\begin{abstract}
The purposes of this study are (1) to longitudinally investigate the percentages of Japanese university English majors who make (a) good progress, (b) little progress, and (c) negative progress in vocabulary learning during specific years in their university studies; and (2) to describe the longitudinal developmental patterns of the students' vocabulary sizes during their first two years of university.

At the beginning of their freshman year ( $1^{\text {st }}$ year $)$, sophomore year ( $2^{\text {nd }}$ year $)$, and junior year ( $3^{\text {rd }}$ year), 109 university students took one of the three parallel forms of Mochizuki's (1998) Vocabulary Size Test (VST). The tests were always administered in April, when the academic year begins in Japan. By comparing the standard errors of difference (SEdiffs) across years, the author examined the progress of students in each year to investigate what percentage of the participants had made good progress, little progress, or negative progress in vocabulary learning. The author also sought to identify developmental patterns in the first half (i.e., the first two years) of students' time at the university.

The results showed that $38.5 \%$ of the participants made good progress, $51.4 \%$ little progress, and $10.1 \%$ negative progress in their vocabulary size during their freshman year. These numbers were $57.8 \%, 26.6 \%$, and $15.6 \%$, respectively, for the sophomore year. Nine longitudinal developmental patterns were found. The most frequent pattern $(31.2 \%)$ is Type $(\rightarrow \uparrow)$, in which students made no progress as freshmen but successfully increased their vocabulary size as sophomores. The other patterns are also described in detail. The study revealed that even English majors did not always increase their vocabulary size in the course of one year.
\end{abstract}

\section{Introduction}

Various kinds of vocabulary tests have been developed and studied (Read, 2000; Nation, 2001). Many focus on breadth of vocabulary knowledge, while others aim at studying the depth of such knowledge, and a few focus on access time. Most vocabulary tests that focus on breadth of vocabulary knowledge measure receptive knowledge; 
others measure productive knowledge. However, despite the range of vocabulary tests available, few studies have utilized them to measure learners' vocabulary knowledge longitudinally.

Longitudinal measurements provide important insights into learners' development of language knowledge and proficiency (e.g., Ortega \& Byrnes [Eds.], 2008). Numerical data on the development of vocabulary size can yield fundamental data on the development of language ability.

Vocabulary size (or receptive knowledge of vocabulary) moderately correlates with English ability among Japanese EFL learners (junior high school students, senior high school [SHS] students, and university students) (Katagiri, 2001). Only a few studies have conducted longitudinal measurements of the receptive knowledge of vocabulary, although some have performed cross-sectional measurements of it (e.g., Yashima, 2002).

Kosuge (2003) measured the vocabulary sizes of Japanese junior high school students longitudinally, utilizing Mochizuki's (1998) Vocabulary Size Tests (VSTs). She showed that most junior high school students increased their receptive knowledge of vocabulary every year.

Katagiri (2009) measured the receptive vocabulary sizes of Japanese SHSs over a period of approximately three years, also utilizing Mochizuki's (1998) VSTs. The results showed that students in the regular course increased their vocabulary sizes in their $1^{\text {st }}$ and $3^{\text {rd }}$ years, but not in their $2^{\text {nd }}$ year, and that students in the English course increased their vocabulary size every year. In addition, in a regular course even at a top-ranking senior high school in the prefecture, $63.9 \%$ of the students made little or negative progress in their $2^{\text {nd }}$ year, and $42.2 \%$ made little or negative progress in their $3^{\text {rd }}$ year. Katagiri noted various longitudinal developmental patterns, including 14 types for students in the regular course and 6 types for those in the English course. In the regular course, the most frequent pattern $(22.5 \%)$ was Type $(\uparrow \rightarrow \uparrow)$, which indicates that the students made good progress in vocabulary size as $1^{\text {st }}$ and $3^{\text {rd }}$ years, but made little progress during their $2^{\text {nd }}$ year. The second most frequent pattern $(18.3 \%)$ in the regular course was Type $(\uparrow \downarrow \uparrow)$, which implies the students made progress in vocabulary size as $1^{\text {st }}$ and $3^{\text {rd }}$ years, but their learning deteriorated in the $2^{\text {nd }}$ year. The third most frequent pattern (15.5\%) in the regular course was Type $(\uparrow \uparrow \uparrow)$, which describes that students made good progress in their vocabulary size during all the three years of high school. In the English course, the most frequent pattern (71.8\%) was Type $(\uparrow \uparrow \uparrow)$, and the second most frequent pattern (15.4\%), Type $(\uparrow \rightarrow \uparrow)$.

Katagiri (2005) cross-sectionally and longitudinally measured the vocabulary sizes of Japanese university students whose major is English, utilizing Mochizuki's (1998) VSTs. Descriptive statistics and estimates of vocabulary size were given for freshmen, sophomores, and juniors; they indicated that, as a whole, higher-grade students had larger vocabulary sizes. Katagiri further reported that $17 \%$ of the university 
students did not make any progress in their vocabulary size and $18 \%$ made negative progress after studying for the two years while freshmen and sophomores.

However, Katagiri's (2005) purpose was not to analyze longitudinal data in detail, and it left room for improvements in the longitudinal analyses. Taking into account the standard error of measurement (SEM) (SEM of Form 2 in the VST that the participants took as freshmen is 157 ; SEM of Form 3 that the participants took as sophomores is 213; SEM of Form 1 that the participants took as juniors is 171), Katagiri temporarily regarded the progress of -249 words to 0 words and 0 words to +249 words as no progress for the sake of convenience. However, the standard error of difference (SEdiff) should have been utilized to strictly judge whether each participant increased his or her vocabulary size.

By reanalyzing the data from Katagiri (2005), this study will (1) longitudinally investigate what percentage of the students made (a) good progress, (b) little progress, and (c) negative progress in their vocabulary learning during specific years; and (2) describe the longitudinal developmental patterns of students' vocabulary sizes during the first two years of their university study.

\section{Method}

\subsection{Participants}

The participants were 109 students majoring in English at a university in Japan. They had been learning English as a foreign language (EFL) since junior high school. As freshmen, they took five university English classes per week; this number increased to six when they became sophomores. Each class consisted of 15 sessions per semester, each 90 minutes long. There were two semesters in the academic year. The investigation took place over two academic years (or four semesters). Thus, the participants spent approximately 495 hours $(1.5$ hours $\times 15$ lessons $\times 5$ classes $\times 2$ semesters +1.5 hours $\times$ 15 lessons $\times 6$ classes $\times 2$ semesters) attending English lessons at the university. The same students had also participated in Katagiri (2005), which showed selected results of macro-analyses of their vocabulary sizes.

\subsection{Materials}

Mochizuki's (1998) VSTs were utilized to measure the participants' receptive knowledge of vocabulary. The VSTs have three forms, labeled as Forms 1, 2, and 3. The forms are confirmed as parallel tests with one another (Katagiri \& Mochizuki, 2002).

Each form has 1,000 - 7,000 word-frequency levels, but test items in the 1,000 word-frequency level were not utilized because a previous study showed that they were too easy for university students (Katagiri, 2000). The test items in the 2,000-7,000 word-frequency levels in the VSTs were utilized in this study.

Mochizuki's original VSTs include 30 test items in each word-frequency level. 
However, the VSTs utilized in this study are revised ones (i.e., simplified versions), which have 26 test items in each word-frequency level for convenience. A sample of the VSTs used in this study is shown in Appendix 1.

Katagiri (2007) examined whether the rationale of estimating receptive vocabulary sizes of Japanese EFL learners through each word-frequency level is appropriate from a psychometrical viewpoint, and it was empirically demonstrated that the rationale is appropriate.

\subsection{Procedure}

The 109 university students took one of the three forms of Mochizuki's VSTs every April at the start of their freshman, sophomore, and junior years as follows: Freshman: Form 2, Sophomore: Form 3, and Junior: Form 1.

The test results were given to the students as feedback in May of each year, with the expectation that they might motivate the students to learn more vocabulary. A sample of such feedback is shown in Appendix 2. The results were also given to the students' teachers as for their reference or to be applied toward teaching.

\section{Results and Discussion}

\subsection{Descriptive Statistics and Test Reliability}

Table 1 shows the means, standard deviations ( $S D s)$, maximums, and minimums of the total scores of the 1,000 - 7,000 word-frequency levels in the VSTs. It also shows reliability indices produced by FACETS (a Rasch measurement computer program), and $S E M \mathrm{~s}^{1}$ for each grade. High reliability indices were confirmed.

Utilizing the $S E M$ values, the $S E d i f f \mathrm{~s}^{2}$ among the three forms are calculated and shown in Table 2.

The mean difference in students' vocabulary size in April of the first and second years $(4650.7-4501.4=149.3)$ is within the SEdiff $(257.0)$. Thus, as a whole, the students did not increase their vocabulary size during their freshman year ${ }^{3}$. Notably, all of them were English majors. The mean difference in April of the second and third years $(5018.7-4650.7=368)$, however, is larger than the SEdiff $(270.8)$. Therefore, as a whole, the students increased their vocabulary size as sophomores.

Generally speaking, variation in learner ability tends to increase after the learners have taken lessons at school or university and studied for a longer period; however, Table 1 shows that the variations (i.e., $S D$ s) of vocabulary size became smaller as the students took more English classes and studied English for a longer period of time. To look into this phenomenon more in detail, the participants' data were divided into three groups (higher, middle, and lower groups) according to the VST scores they obtained when they were freshmen, and the descriptive statistics of their vocabulary sizes of the three groups are calculated and shown in Table 3. We can see from Table 3 that the 
Table 1: VST Scores by University Year

\begin{tabular}{|c|c|c|c|c|c|c|c|c|c|}
\hline $\begin{array}{c}\text { Month } \\
\text { Year }\end{array}$ & VST & $\begin{array}{c}\text { University } \\
\text { Year }\end{array}$ & $N$ & Mean & $S D$ & Max. & Min. & $\begin{array}{c}\text { Reliab } \\
\text {-ility }\end{array}$ & $S E M$ \\
\hline $\begin{array}{c}\text { April } \\
2002\end{array}$ & Form 2 & $\begin{array}{c}\text { Freshman } \\
\left(1^{\text {st }} \text { year }\right)\end{array}$ & 109 & $4,501.4$ & 679.2 & 5,808 & 3,077 & 0.95 & 151.9 \\
\hline $\begin{array}{c}\text { April } \\
2003\end{array}$ & Form 3 & $\begin{array}{c}\text { Sophomore } \\
\left(2^{\text {nd }} \text { year }\right)\end{array}$ & 109 & $4,650.7$ & 598.3 & 6,500 & 3,423 & 0.88 & 207.3 \\
\hline $\begin{array}{c}\text { April } \\
2004\end{array}$ & Form 1 & $\begin{array}{c}\text { Junior } \\
\left(3^{\text {rd }} \text { year }\right)\end{array}$ & 109 & $5,018.7$ & 551.1 & 6,692 & 3,577 & 0.90 & 174.3 \\
\hline
\end{tabular}

Note. VST = Vocabulary Size Test; $N=$ Number of students; $S D=$ standard deviation; Max.$=$ maximum $;$ Min.$=$ minimum; $S E M=$ Standard error of measurement.

Table 2: Standard Error of Difference (SEdiff) by Forms

\begin{tabular}{|c|c|c|c|}
\hline & Between Forms 2 and 3 & Between Forms 3 and 1 & Between Forms 1 and 2 \\
\hline SEdiff & 257.0 & 270.8 & 231.2 \\
\hline
\end{tabular}

Table 3: VST Scores by University Year Among Higher, Middle, and Lower Groups

\begin{tabular}{|c|c|c|c|c|c|}
\hline & \multirow{2}{*}{$N$} & & April 2002 & April 2003 & April 2004 \\
\hline & & & Freshman & Sophomore & Junior \\
\hline \multirow{4}{*}{ A Whole } & \multirow{4}{*}{109} & Mean & $4,501.4$ & $4,650.7$ & $5,018.7$ \\
\hline & & $S D$ & 679.2 & 598.3 & 551.1 \\
\hline & & Max. & 5,808 & 6,500 & 6,692 \\
\hline & & Min. & 3,077 & 3,423 & 3,577 \\
\hline \multirow{4}{*}{ A higher group } & \multirow{4}{*}{36} & Mean & $5,254.2$ & $5,251.1$ & $5,076.9$ \\
\hline & & $S D$ & 264.7 & 392.4 & 514.9 \\
\hline & & Max. & 5,808 & 6,500 & 6,000 \\
\hline & & Min. & 4,923 & 4,346 & 3,577 \\
\hline \multirow{4}{*}{ A middle group } & \multirow{4}{*}{37} & Mean & 4534.3 & 4637.2 & 5084.2 \\
\hline & & $S D$ & 197.8 & 353.3 & 544.1 \\
\hline & & Max. & 4,885 & 5,577 & 6,346 \\
\hline & & Min. & 4,192 & 3,885 & 3,885 \\
\hline \multirow{4}{*}{ A lower group } & \multirow{4}{*}{36} & Mean & 3714.7 & 4064.2 & 4893.2 \\
\hline & & $S D$ & 304.5 & 311.9 & 586.1 \\
\hline & & Max. & 4,115 & 4,731 & 6,692 \\
\hline & & Min. & 3,077 & 3,423 & 3,923 \\
\hline
\end{tabular}

Note. The three groups were classified according to the VST scores the students acquired when they were freshmen. 
lower group increased their VST scores successively while they were freshmen and sophomores and that the higher group did not increase their VST scores while freshmen and sophomores. This may lead to the more convergence into the average and the smaller variations of VST scores as the students studied English for a longer period of time. The author asked their teachers why the higher-group students did not expand their vocabulary size while freshmen and sophomores, and no plausible reasons were obtained. The teachers were just surprised to see this finding.

\subsection{Progress of Each Student Vocabulary Size by University Year}

The numbers and percentages of students who made progress over each SEdiff, who made little or no progress within each SEdiff, and who deteriorated over each SEdiff are shown by university year in Table 4 . It was found that $38.5 \%$ of the participants made good progress, 51.4\% made little progress, and $10.1 \%$ made negative progress in their vocabulary sizes in their freshman year. These numbers were $57.8 \%$, $26.6 \%$, and $15.6 \%$, respectively, for the sophomore year. The author assumes that the yearly progress of the university students majoring in English is probably not as large as what many university teachers and educational researchers expected and that these objective data are new information to teachers and researchers.

Table 4: Progress of Student Vocabulary Size by University Year $(N=109)$

\begin{tabular}{|c|c|c|c|c|}
\hline Change over SEdiff & & Freshman year & Sophomore year & $\begin{array}{c}\text { Freshman and } \\
\text { sophomore } \\
\text { years }\end{array}$ \\
\hline Good progress & $\uparrow$ & $42(38.5 \%)$ & $63(57.8 \%)$ & $70(64.2 \%)$ \\
\hline Little change & $\rightarrow$ & $56(51.4 \%)$ & $29(26.6 \%)$ & $20(18.3 \%)$ \\
\hline Deterioration & $\downarrow$ & $11(10.1 \%)$ & $17(15.6 \%)$ & $19(17.4 \%)$ \\
\hline
\end{tabular}

\subsection{Longitudinal Developmental Patterns}

Using data of the same participants, analyses were conducted to identify longitudinal developmental patterns in vocabulary size during the first two years of university.

If the difference in a student's vocabulary size as measured in the freshman versus sophomore year is larger than 257.0 points (SEdiff between Forms 2 and 3), it is statistically regarded, with a confidence level of $68 \%$, that the student increased his/her vocabulary size while he/she was a freshman. Hereafter, increases of over 257.0 are symbolized as $(\uparrow)$. If the difference is within \pm 257.0 points, it is considered that the student did not make progress in his/her vocabulary size. This is symbolized as $(\rightarrow)$. Then, if a difference is less than -257.0 points, the student's vocabulary size is considered to have decreased. This type is symbolized as $(\downarrow)$. 
Table 5: Longitudinal Developmental Patterns $(N=109)$

\begin{tabular}{|c|c|c|c|c|}
\hline Pattern type & Freshman year & Sophomore year & $N$ & $\%$ \\
\hline 1 & $\uparrow$ & $\uparrow$ & 24 & $22.0 \%$ \\
\hline 2 & $\uparrow$ & $\rightarrow$ & 11 & $10.1 \%$ \\
\hline 3 & $\uparrow$ & $\downarrow$ & 7 & $6.4 \%$ \\
\hline 4 & $\rightarrow$ & $\uparrow$ & 34 & $31.2 \%$ \\
\hline 5 & $\rightarrow$ & $\rightarrow$ & 14 & $12.8 \%$ \\
\hline 6 & $\rightarrow$ & $\downarrow$ & 8 & $7.3 \%$ \\
\hline 7 & $\downarrow$ & $\uparrow$ & 5 & $4.6 \%$ \\
\hline 8 & $\downarrow$ & $\rightarrow$ & 4 & $3.7 \%$ \\
\hline 9 & $\downarrow$ & $\downarrow$ & 2 & $1.8 \%$ \\
\hline & Total & & 109 & $100 \%$ \\
\hline
\end{tabular}

Note. $N=$ Number of students.

Similar judgments using a criterion of 270.8 points (SEdiff between Forms 3 and 1) were made for each student's development between the sophomore and junior year.

Various developmental patterns emerged, and they were classified into nine pattern types, which is the same as the theoretical maximum number of pattern types. Table 5 lists these types along with the number and percentage of students who displayed each one.

The most frequent pattern $(31.2 \%)$ is Type $4(\rightarrow \uparrow)$, in which students made no progress in their receptive vocabulary sizes during their freshman year but did make progress as sophomores. The second most frequent pattern $(22.0 \%)$ is Type $1(\uparrow \uparrow)$, which indicates that they made progress in both their freshman and sophomore years. The third most frequent pattern (12.8\%), Type $5(\rightarrow \rightarrow)$, describes that they made no progress in each either year.

\subsection{Discussion}

Many teachers, students, and educational researchers believe that, in general, students increase their English vocabulary size every year. However, this study shows that the presumption is not true. Only $22.0 \%$ of participants in this study increased their vocabulary size favorably each year. This findings accords with Katagiri (2009), which showed that, even at a top-ranking high school, $63.9 \%$ of the students in the regular course made little or negative progress in their vocabulary learning during their sophomore year, and $42.2 \%$ made little or negative progress in their junior year. Katagiri (2009) also identified as many as 14 longitudinal developmental patterns in the vocabulary learning of SHSs in the regular course. The results of this study also accord with Katagiri (2010). Part of the results of Katagiri (2010) are shown in Table 6, which 
Table 6: Examining the Progress of Each Student of SHS students in Each Year

(Katagiri 2010, p. 225)

\begin{tabular}{|c|c|c|c|c|c|c|c|}
\hline & & & & $\begin{array}{l}\text { During the } \\
1^{\text {st }} \text {-year of } \\
\text { SHS }\end{array}$ & $\begin{array}{l}\text { During the } \\
2^{\text {nd }} \text {-year of } \\
\text { SHS }\end{array}$ & $\begin{array}{l}\text { During the } \\
3^{\text {rd }} \text {-year of } \\
\text { SHS }\end{array}$ & $\begin{array}{l}\text { During the } 3 \\
\text { years of SHS } \\
\left(1^{\left.\text {st to } 3^{\text {rd }}\right)}\right.\end{array}$ \\
\hline \multirow{6}{*}{ 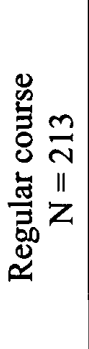 } & \multirow{3}{*}{$\mathrm{L}$} & Progress over SEdiff & $\uparrow$ & $35(16.4 \%)$ & $35(16.4 \%)$ & $40(18.8 \%)$ & $71(33.3 \%)$ \\
\hline & & Little change within $S E$ diff & $\rightarrow$ & $163(76.5 \%)$ & $162(76.1 \%)$ & $138(64.8 \%)$ & $123(57.7 \%)$ \\
\hline & & Deterioration over SEdiff & $\downarrow$ & $15(7.0 \%)$ & $16(7.5 \%)$ & $35(16.4 \%)$ & $19(8.9 \%)$ \\
\hline & \multirow{3}{*}{ R } & Progress over SEdiff & $\uparrow$ & $67(31.5 \%)$ & $38(17.8 \%)$ & $80(37.6 \%)$ & $114(53.5 \%)$ \\
\hline & & Little change within $S E$ diff & $\rightarrow$ & $123(57.7 \%)$ & $132(62.0 \%)$ & $104(48.8 \%)$ & $68(31.9 \%)$ \\
\hline & & Deterioration over SEdiff & $\downarrow$ & $23(10.8 \%)$ & $43(20.2 \%)$ & $29(13.6 \%)$ & $31(14.6 \%)$ \\
\hline
\end{tabular}

showed that the percentage of students in the regular course who made progress during their $1^{\text {st }}$ year, $2^{\text {nd }}$ year, and $3^{\text {rd }}$ year of senior high school was only $16.4 \%, 16.4 \%$, and $18.8 \%$, respectively, in listening scores of TOEIC Bridge and $31.5 \%, 17.8 \%$, and $37.6 \%$, respectively, in reading scores of the same.

Recently, complexity theory, dynamic systems theory, complex adaptive systems theory, and chaos theory have drawn attention in the field of applied linguistics, where attempts have been made to apply them (Larsen-Freeman \& Cameron, 2008; Ellis \& Larsen-Freeman [Eds.], 2009; Verspoor, de Bot, \& Lowie [Eds.], 2011). These theories are similar to one another, but they differ in some regards. "Complexity theory deals with the study of complex, dynamic, non-linear, self-organizing, open, emergent, sometimes chaotic, and adaptive systems" (Larsen-Freeman \& Cameron, 2008, p. 4). Dynamic systems theory considers that linguistic skills can grow and decline; its characteristics are following: (a) sensitive dependence on initial conditions, (b) complete interconnectedness, (c) nonlinearity in development, (d) change through internal reorganization and interaction with the environment, (e) dependence on internal and external resources, (f) constant change, with chaotic variation sometimes, in which the systems only temporarily settle into "attractor states," (g) iteration, which means that the present level of development depends critically on the previous level, (h) change caused by interaction with the environment and internal reorganization, and (i) emergent properties (de Bot \& Larsen-Freeman, 2011). Meara (1997, 2004, 2006) used a complex systems approach or dynamic modeling to describe vocabulary development or loss. Complex adaptive system approaches consider, "The system is adaptive; that is, speakers' behavior is based on their past interactions, and current and past interactions together feed forward into future behavior" (Beckner et al., 2009, p. 2). "Chaos theory is the study of non-linear dynamical systems, i.e. systems that do not unfold over time in a linearly predictable manner" (Larsen-Freeman \& Cameron, 2008, p. 4). From the viewpoints of complexity theory, dynamic systems theory, complex adaptive systems theory, or chaos theory, the results of this study and Katagiri (2009) might support that 
vocabulary learning and learners' longitudinal development in vocabulary size are complex, dynamic, and non-linear.

Longitudinal measurements of each EFL learners' vocabulary sizes seemed to provide the learners and their teachers with fundamental data on their long-term vocabulary development. Curriculum and syllabus design should take into account the various development patterns of vocabulary size. From the viewpoint of the portfolio in which learners accumulate learning materials and contents and sometimes review them, it appears helpful for language learning if EFL learners accumulate the data of their longitudinal measurements and review them occasionally to motivate themselves to learn more. Japanese EFL learners, in particular, seem to benefit from confirmations of their English progress through objective numerical data, because they have few opportunities to practice English in their daily lives and, therefore, few opportunities to feel that their English has improved through life experience or communication. Future studies should provide more longitudinal measurements of Japanese junior high school, senior high school, and university students' EFL vocabulary knowledge.

\subsection{Limitations and Suggestions for Future Research}

Only university students majoring in English participated in this study. Further research should explore the same topic with university students majoring in a variety of academic fields, such as the social sciences and natural sciences.

Moreover, Mochizuki's VSTs were utilized in this study because the author considered them appropriate to measure the vocabulary size of Japanese EFL learners (Katagiri, 2001). If other vocabulary size tests had been utilized, the results might have been affected accordingly.

This study focused on the receptive knowledge of vocabulary. Longitudinal measurements of the productive knowledge of vocabulary are expected in future research. Longitudinal measurements of the depth of knowledge of vocabulary are also of interest.

In this study, longitudinal measurements were conducted only for the first two years of university learning. Measurements spanning longer periods may be expected. However, in Japan, university juniors begin searching for jobs in the second half of the academic year. Their job search activities and related preparations often take precedence over studying; therefore, juniors spend much less time learning English than freshman and sophomore students.

Finally, more studies that include longitudinal measurements of vocabulary knowledge are needed to support the findings here. Adding to measurements of vocabulary knowledge, longitudinal quantitative measurements or qualitative observations of other aspects of English language competency (proficiency) and learners' motivations are also expected to be conducted longitudinally. 


\section{Conclusion}

The purposes of this study were (1) to longitudinally investigate what percentage of the students made (a) good progress, (b) little progress, and (c) negative progress in vocabulary learning during specific years in their university studies; and (2) to describe the longitudinal developmental patterns of students' vocabulary size during their first two years of university.

In relation to the first purpose, it was found that $38.5 \%$ of the participants made good progress, $51.4 \%$ made little progress, and $10.1 \%$ made negative progress in their vocabulary sizes in their freshman year. These numbers were $57.8 \%, 26.6 \%$, and $15.6 \%$, respectively, for the sophomore year.

Regarding the second purpose of the study, nine longitudinal developmental patterns were found. The most frequent pattern $(31.2 \%)$ is Type $4(\rightarrow \uparrow)$, which means that the students made no progress in their receptive vocabulary sizes during their freshman year, but they made progress as sophomores. The second most frequent pattern $(22.0 \%)$ is Type $1(\uparrow \uparrow)$, which indicates that students made progress in both their freshman and sophomore years. The third frequent pattern $(12.8 \%)$, Type $5(\rightarrow \rightarrow)$, describes that they made no progress in either year.

\section{Notes}

* The results of this paper were reported at a poster presentation at the Conference of the American Association for Applied Linguistics in Boston, U.S.A, on March 26, 2012.

1. The mathematical formula of standard error of measurement $(S E M)$ is:

$S D^{*} \operatorname{sqrt}(1-r)$.

(Note. $S D=$ standard deviation; $r=$ reliability index)

If one respondent takes the same test twice with an interval of some time and the difference (increase or decrease) of the two scores is over the points of $S E M$, it is statistically regarded that there is a difference (increase or decrease) between the previous test score and the latter with a confidence level of $68 \%$. If the difference is over the double of $S E M$, it is that there is a difference with a confidence level of 95\%. (Here, repetition effects are neglected.)

2. The mathematical formula of standard error of difference (SEdiff) is:

$\operatorname{sqrt}\left[\left(S E M_{1}\right)^{2}+\left(S E M_{2}\right)^{2}\right]$.

(Note. $S E M_{1}=S E M$ of the first parallel form of the tests;

$S E M_{2}=S E M$ of the second parallel form.)

If one respondent takes the TWO parallel forms of the tests and the difference (increase or decrease) of the two scores is over the points of SEdiff, it is statistically 
regarded that there is a difference (increase or decrease) between the previous test score and the latter with a confidence level of $68 \%$. If the difference is over the double of SEdiff, it is that there is a difference with a confidence level of $95 \%$.

3. Some researchers use the double of SEdiff as a criterion to examine whether there is a difference (increase or decrease) between the previous test score and the latter with a confidence level of $95 \%$. Generally speaking, a higher confidence level should be expected. However, the author adopted the single of SEdiff as a criterion to examine whether there is a difference with a confidence level of $68 \%$, because the double of SEdiff seemed too strict as the criterion, judging from Tables 1 and 4.

\section{Acknowledgement}

* This paper was funded by a Senshu University research grant in academic year 2009, the research topic submitted to which was “外国語学習者における受容語彙知識の発 達の綐断的調査と分析：英語専攻の大学生を被験者として.” I am thankful to Senshu University.

* I appreciate anonymous reviewers who gave me insightful comments.

\section{References}

Beckner, C., Ellis, N., Blythe, R., Holland, J., Bybee, J., Ke, J., ...Schoenemann, T. (2009). Language is a complex adaptive system: position paper. In N. Ellis, \& D. Larsen-Freeman (Eds.), Language as a Complex Adaptive System (pp. 1-26). Chichester, U.K.: Wiley-Blackwell.

de Bot, K., \& Larsen-Freeman, D. (2011). Researching second language development from a dynamic systems theory perspectives. In M. H. Verspoor, K. de Bot, \& W. Lowie (Eds.), A Dynamic Approach to Second Language Development: Methods and Techniques (pp. 5-23). Amsterdam, The Netherlands: John Benjamins Publishing Company.

Ellis, N., \& Larsen-Freeman, D. (Eds.). (2009). Language as a Complex Adaptive System. Chichester, U.K.: Wiley-Blackwell.

Katagiri, K. (2000). Quick and rough estimates of general English ability, using Mochizuki's Vocabulary Size Test for Japanese EFL learners. The Japan Language Testing Association Journal, 3, 83-99.

Katagiri, K. (2001). Developing the Ten-Minute Vocabulary Tests for Quick and Approximate Estimates of General English Ability of Japanese EFL Learners. Unpublished Ph.D. thesis submitted to Tokyo Gakugei University.

Katagiri, K. (2005). A practical report: Conducting Vocabulary Size Tests at university every year. JACET Summer Seminar Proceedings, 3, 70-76. 
Katagiri, K. (2007). Examining the rationale of vocabulary size tests based on word-frequency levels. The Japan Language Testing Association Journal, 10, 36-55.

Katagiri, K. (2009). A three-year longitudinal study of vocabulary size in Japanese SHS students and a description of their developmental patterns. ARELE, 20,131-140.

Katagiri, K. (2010). Three-year longitudinal study of the progress in listening and reading proficiency of Japanese senior high school students and their developmental patterns. ARELE, 21, 221-230.

Katagiri, K., \& Mochizuki, M. (2002, August). Goi Saizu Tesuto: Mittsu no han no heikousei [Mochizuki's (1998) Vocabulary Size Test: the parallelism of the three forms]. Paper presented at the $28^{\text {th }}$ annual meeting of the Japan Society of English Language Education, Kobe, Japan.

Kasahara. K. (2006). Producing a revised version of the Mochizuki Vocabulary Size Test. The Japan Language Testing Association Journal, 9, 55-66.

Kosuge, A. (2003). Goi saizu tesuto kara mita goi no shuutoku [Looking into vocabulary aquisition, utilizing the results of vocabulary size tests]. In $\mathrm{H}$. Ohta, K. Kanatani, A. Kosuge, \& S. Hidai, Eigo ryokuwa donoyounishite nobiteyukuka [How are Japanese EFL learners' English ability developed?]. Tokyo: Taishuukan Shoten.

Larsen-Freeman, D., \& Cameron, L. (2008). Complex Systems and Applied Linguistics. Oxford, U.K.: Oxford University Press.

Meara, P. (1997). Towards a new approach to modeling vocabulary acquisition. In N. Schmitt, \& M. McCarthy (Eds.), Vocabulary: Description, Acquisition and Pedagogy (pp. 109-121). Cambridge, U.K.: Cambridge University Press.

Meara, P. (2004). Modelling vocabulary loss. Applied Linguistics, 25(2), 137-155.

Meara, P. (2006). Emergent properties of multilingual lexicons. Applied Linguistics, 27(4), 620-644.

Mochizuki, M. (1998). Nihonjin eigo gakushusha no tameno goi saizu tesuto [A Vocabulary Size Test for Japanese learners of English]. The Institute for Research in Language Teaching Bulletin, 12, 27-53.

Nation, P. (2001). Learning Vocabulary in Another Language. Cambridge, U.K.: Cambridge University Press.

Ortega L., \& Byrnes H. (Eds.). (2008) The Longitudinal Study of Advanced L2 Capacities. New York, NY: Routledge.

Read, J. (2000). Assessing Vocabulary. Cambridge, U.K.: Cambridge University Press.

Verspoor, M. H., de Bot, K., \& Lowie, W. (Eds.). (2011). A Dynamic Approach to Second Language Development: Methods and Techniques. Amsterdam, The Netherlands: John Benjamins Publishing Company.

Yashima, H. (2002). Nihonjin koukousei no goi saizu [The vocabulary size of 
Japanese EFL senior high school students]. The Bulletin of the Kanto-KoshinEtsu English Language Education Society, 16, 29-41.

\section{Appendix 1}

\section{A Sample of a Slightly Revised Version of Mochizuki's (1998) Vocabulary Size Tests}

7,000 Word Level（Form II )

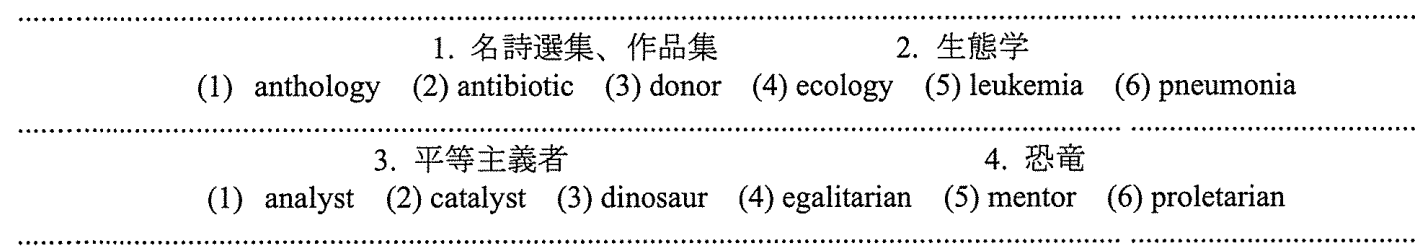
23. 器用な、巧みな
24. 筋の通った、首尾一貫した
(1) coherent
(2) competent
(3) deft
(4) eminent
(5) extinct
(6) staunch

25. 発明の才がある、利口な 26. 道理のわからない、不合理な
(1) autonomous
(2) definitive
(3) feasible
(4) illicit
(5) ingenious
(6) irrational

\section{Appendix 2}

\begin{tabular}{|c|c|c|c|c|c|c|c|c|c|c|c|c|c|}
\hline \multicolumn{14}{|c|}{ A Sample of the Feedback to the Students } \\
\hline \# & $\begin{array}{l}\text { 学 } \\
\text { 年 }\end{array}$ & 氏名 & $\begin{array}{l}\text { 語L } \\
\text { ヘル }\end{array}$ & $\begin{array}{l}2.000 \\
\text { 語L } \\
\text { ヘル }\end{array}$ & $\begin{array}{l}3,000 \\
\text { 語L } \\
\text { ヘル }\end{array}$ & $\begin{array}{l}4.000 \\
\text { 語L } \\
\text { ベル }\end{array}$ & $\begin{array}{l}5,000 \\
\text { 語し } \\
\text { ベル }\end{array}$ & $\begin{array}{l}6,000 \\
\text { 語し } \\
\text { ヘル }\end{array}$ & $\begin{array}{l}\text { 語L } \\
\text { ベル }\end{array}$ & 合計 & 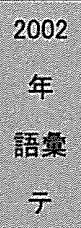 & $\begin{array}{c}2003 \\
\text { 年 } \\
\text { 語商 } \\
\text { T }\end{array}$ & $\begin{array}{c}2004 \\
\text { 年 } \\
\text { 語咅 } \\
\text { T }\end{array}$ \\
\hline 1 & 3 & 太郎 & 1,000 & 962 & 923 & 692 & 846 & 615 & 231 & 5,269 & 4,462 & 4,769 & 5,269 \\
\hline 2 & 3 & 次郎 & 1,000 & 1,000 & 846 & 808 & 769 & 692 & 308 & 5,423 & 4,192 & 4,846 & 5,423 \\
\hline 3 & 3 & 三郎 & 1,000 & 1,000 & 923 & 885 & 846 & 731 & 385 & 5,769 & 5.462 & 5,731 & 5,769 \\
\hline 4 & 3 & 梅子 & 1,000 & 1,000 & 885 & 808 & 808 & 577 & 385 & 5,462 & 4,577 & 4,500 & 5,462 \\
\hline 5 & 3 & 花子 & 1,000 & 1,000 & 692 & 692 & 769 & 615 & 192 & 4,962 & 4,923 & 4,885 & 4,962 \\
\hline 6 & 3 & 五郎 & 1,000 & 731 & 577 & 462 & 538 & 154 & 115 & 3,577 & 5,538 & 5,192 & 3,577 \\
\hline
\end{tabular}

